\title{
Pengaruh Hak Kepemilikan Sawah Terhadap Pemberdayaan Petani Perempuan Di Desa Sumberharjo, Prambanan, Sleman, DIY
}

\author{
Nurisqi Amalia ${ }^{1}$, Nur Aini Yuniyarti ${ }^{2}$, Eka Mariyanti ${ }^{3}$ \\ ${ }^{1}$ Program Studi D4 Manajemen dan Penilaian Properti, Departemen Ekonomika \\ dan Bisnis, Sekolah Vokasi, Universitas Gadjah Mada \\ 2,3Program Studi D3 Ekonomika Terapan, Departemen Ekonomika dan Bisnis, \\ Sekolah Vokasi, Universitas Gadjah Mada \\ Corresponding Author: nurisqi.amalia@ugm.ac.id
}

\begin{abstract}
ABSTRAK
Tujuan penelitian ini adalah untuk mengetahui pengaruh kepemilikan sawah terhadap pemberdayaan petani perempuan di Desa Sumberharjo, Kecamatan Prambanan. Data primer dikumpulkan melalui wawancara terhadap 74 petani perempuan di Desa Sumberharjo. Alat analisis yang digunakan adalah statistik deskriptif dan analisis SWOT. Hasil penelitian menunjukkan bahwa: 1) Rata-rata pendapatan petani perempuan buruh lebih besar dibandingkan petani perempuan yang memiliki sawah; 2) Mayoritas petani perempuan buruh memiliki pendidikan SD, sementara pendidikan petani perempuan yang memiliki sawah didominasi oleh petani yang berpendidikan SD dan tidak mengenyam pendidikan; 3) Petani perempuan pemilik sawah memiliki kesempatan yang lebih besar untuk meningkatkan pemberdayaan perempuan melalui akses media sosial atau media informasi; 4) Masih terdapat petani perempuan yang menyatakan bahwa ada beberapa kegiatan yang hanya bisa dihadiri oleh petani perempuan yang memiliki sawah. Selain itu, petani perempuan lebih mudah mendapatkan informasi tentang pertanian jika memiliki lahan sendiri. Mereka dapat memperoleh informasi dari kelompok tani perempuan di desanya; 5) Secara umum strategi untuk petani perempuan pemilik sawah adalah memanfaatkan HP maupun media sosial untuk meningkatkan pemberdayaan perempuan petani, terutama dalam hal komunikasi dan pemasaran. Sementara itu, bagi petani perempuan buruh, peningkatan skill pertanian dan keaktivan dalam komunitas atau kelompok buruh merupakan peran penting dalam membantu meningkatkan pemberdayaan petani perempuan buruh.
\end{abstract}

Kata kunci: buruh tani, kepemilikan sawah, pemberdayaan perempuan, petani perempuan

\section{PENDAHULUAN}

The Sustainable Development Goals (SDGs) atau dikenal sebagai The Global Goals adalah istilah universal untuk mengakhiri kemiskinan, melindungi planet dan memastikan bahwa semua orang di dunia menikmati perdamaian dan kemakmuran, sekarang dan masa depan. SDGs merupakan blueprint bersama untuk perdamaian dan kemakmuran yang terdiri dari 17 Gol yang dibangun untuk tujuan pembangunan Milenium, dan kesetaraan gender merupakan target gol ke-5 dari SDGs (www.undp.org). Kesetaraan gender menjadi salah satu target pembangunan berkelanjutan karena diskriminasi berdasarkan gender masih terjadi pada seluruh aspek kehidupan, di seluruh dunia. 
Di Indonesia, permasalahan kesetaraan gender ditangani secara khusus oleh Kementerian Pemberdayaan Perempuan dan Perlindungan Anak (Kemenpppa). Kementerian dengan tagline "Mencapai kesetaraan gender dan memberdayakan kaum perempuan" menyatakan bahwa kesetaraan gender dapat memperkuat kemampuan negara untuk berkembang, mengurangi kemiskinan, dan memerintah secara efektif. Menurut Anukriti (2014), perempuan di banyak negara berkembang telah lama menghadapi diskriminasi gender. Diskriminasi ini secara fundamental didorong oleh pandangan masyarakat bahwa perempuan merupakan aktor yang kurang produktif dalam perekonomian. Hal tersebut karena kurangnya keterlibatan langsung dalam kegiatan yang menghasilkan pendapatan dan hal tersebut kurang menguntungkan bagi para orangtua yang berorientasi pada akumulasi aset jangka panjang. Sementara itu, Janssens (2010) menemukan bahwa perempuan yang lebih memberdayakan kemampuannya lebih cenderung untuk berpartisipasi dalam proyek pengembangan masyarakat seperti konstruksi dan pemeliharaan sekolah, jalan, dan jembatan. Ketidaksetaraan gender atas wanita juga berkaitan dengan kepemilikan properti. Peningkatan akses perempuan terhadap sumber daya, termasuk hak kepemilikan atas properti, menghasilkan investasi yang lebih tinggi seperti pendidikan, Kesehatan, dan gizi. (Menon, van der Meulen Rodgers, \& Nguyen, 2014; Wiig, 2013; Pandey, 2010; Anderson \& Eswaran, 2009; Doss, 2006; Duflo, 2003; Mason, 1996; dan Thomas, 1990). Terdapat berbagai jenis barang yang dapat dikategorikan sebagai properti, antara lain adalah tanah. Tanah merupakan salah satu wujud dari real property.

Sebagai negara agraris, salah satu properti di Indonesia berwujud lahan pertanian. Kabupaten Sleman merupakan wilayah dengan luas lahan sawah terbesar di Daerah Istimewa Yogyakarta (DIY). Menurut data Badan Pusat Statistik (BPS) Provinsi DIY (2014), Kabupaten Sleman merupakan wilayah dengan luas lahan sawah terbesar di DIY. Sementara itu, berdasarkan data BPS Kabupaten Sleman (slemankab.bps.go.id) bahwa luas panen dan rata-rata produksi pertanian (jagung, kedelai, dan padi sawah) terbesar di Kabupaten Sleman berada di Kecamatan Prambanan. Sementara itu, jumlah kepala keluarga perempuan terbesar yang bekerja di Sektor Pertanian/Peternakan/Perikanan di Kecamatan Prambanan adalah Desa Sumberharjo yaitu 350 jiwa (kependudukan.jogjaprov.go.id). Di daerah pedesaan di mana pertanian adalah sumber utama pendapatan, secara keliru perempuan telah dianggap kurang berharga, sebagian besar perempuan terlibat dalam pekerjaan rumah tangga dan kurang terlibat langsung dalam kegiatan yang menghasilkan pendapatan. Persepsi ini diperburuk di daerah pedesaan atas sentralitas kepemilikan tanah, karena perempuan umumnya memiliki akses terbatas ke tanah. Meskipun mayoritas para wanita merupakan tenaga kerja di bidang pertanian di negara berkembang (SOFA Team \& Doss, 2011), mereka hanya mengendalikan sekitar 19\% dari kepemilikan lahan pertanian (FAO., 2010). Penelitian yang dilakukan oleh Prasekti (2017) menyimpulkan bahwa peran wanita tani dalam menunjang perekonomian rumah tangga keluarga petani di Desa Ngubalan Kecamatan Kalidawir Kabupaten Tulungagung, para wanita 
tani telah ikut ambil bagian dalam menambah pendapatan keluarga untuk membantu suami yang penghasilannya kecil. Selain bekerja menjadi wanita tani, mereka tidak melupakan tanggung jawab mereka sebagai ibu rumah tangga. Secara otomatis perannnya menjadi ganda, yaitu menjadi ibu rumah tangga dan sebagai istri yang bekerja. Dalam mengoptimalkan peran tersebut, perempuan memerlukan perubahan positif untuk menuju kesetaraan gender. Perubahan diharapkan terjadi dari program pemberdayaan.

Pemberdayaan adalah proses memberikan kesempatan kepada seseorang atau lebih untuk berpikir, berbicara, bertindak, berkeputusan terkait dengan pekerjaannya sehingga pekerjaan lebih cepat, singkat, dan mudah. Masyarakat konvensional diharapkan untuk berubah menjadi komunitas yang lebih dinamis yang secara aktif terlibat secara mandiri dalam menemukan potensi yang ada di masyarakat itu sendiri. Selain itu, program pemberdayaan terutama difokuskan pada masyarakat di suatu negara dalam upaya memperluas sistem usaha pertanian melalui ekspansi pertanian (Saragih, 2000; Suparta, 2001). Menurut United Nations (www.un.org), prinsip pemberdayaan perempuan secara singkat adalah untuk: 1) membentuk kepemimpinan di perusahaan dengan menjunjung kesetaraan gender; 2) memperlakukan semua perempuan dan laki-laki secara adil di dalam perusahaan (menghormati dan mendukung hak asasi manusia, nondiskriminasi); 3) memastikan kesehatan, keselamatan, dan kesejahteraan semua pekerja perempuan dan laki-laki; 4) mempromosikan pendidikan, pelatihan dan pengembangan profesional bagi perempuan; 5) melaksanakan pengembangan usaha, rantai pasokan dan praktik pemasaran yang memberdayakan perempuan; 6) meningkatkan kesetaraan melalui prakarsa masyarakat dan advokasi; dan 7) mengukur dan melaporkan kemajuan pada publik untuk mencapai kesetaraan gender. Berdasarkan diskusi diatas, penelitian ini bertujuan untuk mengetahui pengaruh kepemilikan sawah terhadap pemberdayaan petani perempuan di Desa Sumberharjo, Kecamatan Prambanan, Kabupaten Sleman, DIY. Dengan tujuan tersebut diharapkan dapat meningkatkan kesejahteraan perempuan melalui pemberdayaan, khususnya petani perempuan.

\section{METODE PENELITIAN}

Penelitian ini memodifikasi penelitian Mishra \& Sam (2016). Terdapat tiga hal yang membedakan penelitian Mishra \& Sam (2016) dengan penelitian ini. Pertama, pemberdayaan perempuan pada penelitian Mishra \& Sam (2016) diproksikan dengan variabel keputusan rumah tangga di bidang perawatan kesehatan, pembelian kebutuhan rumah tangga, dan kunjungan ke keluarga atau kerabat. Sementara dalam penelitian ini berfokus pada akses informasi. Kedua, pemilihan alat analisis. Penelitian Mishra \& Sam (2016) menggunakan regresi logistik multinomial. Sedangkan penelitian ini menggunakan statistik deskriptif. Ketiga, sumber data. Penelitian Mishra \& Sam (2016) menggunakan data sekunder yang bersumber dari 
Nepal Demographic and Health Surveys, sementara penelitian ini menggunakan data primer yang dikumpulkan melalui wawancara secara langsung pada petani perempuan di Desa Sumberharjo.

Sampel dalam penelitian ini adalah 78 petani perempuan di Desa Sumberharjo, Kecamatan Prambanan, Kabupaten Sleman, DIY. Jumlah tersebut diperoleh dari populasi yang berjumlah 350 jiwa melalui Rumus Slovin dengan teknik random sampling.

\section{Statistik Deskriptif}

Statistik deskriptif adalah statistik yang digunakan untuk menganalisis data dengan cara mendeskripsikan atau menggambarkan data yang telah terkumpul sebagaimana adanya tanpa bermaksud membuat kesimpulan yang berlaku untuk umum atau generalisasi (Sugiyono, 2017). Penelitian statistik deskriptif memberikan gambaran atau deskriptif suatu data yang dapat dilihat dari nilai rata-rata (mean), standar deviasi, varians, dan maksimum-minimum (Ghozali, 2011). Dalam penelitian ini, statistik deskriptif digunakan untuk menentukan rata-rata pendapatan petani perempuan di Desa Sumberharjo. Rumus mean sebagai berikut:

$\bar{x}=\frac{\sum_{i=1}^{n} x_{i}}{n}=\frac{x_{1}+x_{2}+\cdots+x_{n}}{n}$

di mana:

$\begin{array}{ll}\overline{\mathrm{X}} & \text { : rata-rata sampel } \\ \mathrm{Xn} & \text { : data observasi } \\ \mathrm{n} & : \text { ukuran sampel }\end{array}$

Untuk mengetahui karakteristik pendidikan antara petani perempuan yang memiliki sawah dan buruh, digunakan alat analisis Tabulasi Silang (Crosstabs). Pengertian Tabulasi Silang (Crosstabs) adalah metode analisis yang paling sederhana tetapi memiliki daya menerangkan cukup kuat untuk menjelaskan hubungan antar variabel. Tabulasi Silang digunakan untuk data kategorikal dalam bentuk tabulasi yang terdiri dari baris (row) dan kolom (column).

Sementara itu, untuk mengetahui tingkat akses media, kegiatan yang bisa dihadiri, dan kemudahan mendapatkan informasi bagi petani perempuan dihitung menggunakan persentase dengan rumus sebagai berikut:

$\mathrm{P}=(\mathrm{F} / \mathrm{N}) \times 100 \%$

di mana:

P : Persentase

F : Jumlah responden yang menjawab dengan pilihan sama

$\mathrm{N} \quad$ : Jumlah seluruh responden 


\section{Analisis SWOT (Strengths, Weaknesses, Opportunities, Threats)}

Menurut Rangkuti (2006), SWOT adalah identifikasi berbagia faktor secara sistematis untuk merumuskan strategi perusahaan. Analisis ini didasarkan pada logika yang dapat memaksimalkan kekuatan ((Strengths) dan peluang (Opportunities), namun secara bersamaan dapat meminimalkan kelemahan (Weaknesses) dan ancaman (Threats). SWOT adalah singkatan dari lingkungan internal yaitu Strengths dan Weaknesses serta lingkungan eksternal yaitu Opportunities dan Threats yang dihadapi.

\section{HASIL DAN PEMBAHASAN}

\section{Rata-Rata Pendapatan Petani Perempuan}

Responden dalam penelitian ini adalah petani perempuan di Desa Sumberharjo, Kecamatan Prambanan, Kabupaten Sleman sebanyak 74 orang. Berdasarkan hasil wawancara, pendapatan yang diterima petani perempuan adalah sebagai berikut:

1) Rata-rata Pendapatan Petani Perempuan Pemilik Sawah

Dari 37 responden petani perempuan pemilik sawah, 36 petani menjawab rata-rata pendapatan yang diterima dari hasil bertani adalah sebesar Rp762.944 per bulan. Dan sisanya 1 petani menjawab rata-rata pendapatan yang diterima dari bertani adalah Rp10.000 per hari. Kedua jangka waktu tersebut (per bulan dan per hari) tidak dapat disamaratakan karena pendapatan petani bukan merupakan pendapatan tetap.

\section{2) Rata-rata Pendapatan Petani Perempuan Buruh}

Dari 37 responden petani perempuan buruh, 1 petani menjawab rata-rata pendapatan yang diterima dari hasil bertani adalah sebesar Rp80.000 per 3 bulan, 26 petani menerima Rp856.961 per bulan, 7 petani menerima Rp42.857 per hari. Dan sisanya 3 petani tidak menjawab berapa rata-rata pendapatan yang diterima dari hasil bertani. Sama halnya seperti pendapatan petani perempuan pemilik sawah, pendapatan yang diterima petani perempuan dari hasil bertani bukan merupakan pendapatan tetap, sehingga terdapat tiga jenis pendapatan yang disebutkan yaitu rata-rata pendapatan per tiga bulan, per bulan, dan per hari.

Dari uraian tersebut, diketahui bahwa pendapatan per bulan merupakan jenis pendapatan yang mendominasi baik bagi petani perempuan pemilik sawah maupun petani perempuan buruh. Perbandingan rata-rata pendapatan per bulan kedua petani tersebut dapat disajikan dalam Tabel 1 berikut:

Tabel 1. Perbandingan Rata-rata Pendapatan antara Petani Perempuan Pemilik Sawah dan Buruh

\begin{tabular}{ll}
\hline Pemilik Sawah & Buruh \\
\hline Rp762.944 & Rp856.961 \\
\hline
\end{tabular}

Sumber: Data primer, diolah (2019)

Tabel 1 menunjukkan bahwa rata-rata pendapatan hasil bertani petani perempuan buruh lebih besar dibandingkan petani perempuan pemilik sawah. Berdasarkan hasil 
wawancara, hal tersebut karena petani buruh tidak hanya menggarap satu sawah saja, sedangkan pemilik sawah hanya menerima hasil hanya dari sawahnya.

\section{Karakteristik Petani Perempuan Berdasarkan Status Kepemilikan dan Pendidikan}

Pendidikan yang ditempuh berdasarkan status kepemilikan petani perempuan di Desa Sumberharjo adalah sebagai berikut:

Tabel 2. Tabulasi Silang Karakteristik Petani Perempuan Berdasarkan Status Kepemilikan dan Pendidikan

\begin{tabular}{lllllll}
\hline & \multicolumn{5}{c}{ Pendidikan } & Tot \\
\cline { 2 - 6 } & $\begin{array}{l}\text { Tdk } \\
\text { Sekolah }\end{array}$ & SD & SMP & $\begin{array}{l}\text { SM } \\
\text { A }\end{array}$ & PT \\
\hline Pemilik & 10 & 10 & 7 & 8 & 2 & 37 \\
Sawah & & 16 & 7 & 6 & 0 & 37 \\
Buruh & 8 & 26 & 14 & 14 & 2 & 74 \\
Total & 18 & \multicolumn{6}{c}{ Sumber: Data primer, diolah (2019) } \\
\hline \multicolumn{6}{c}{}
\end{tabular}

Berdasarkan Tabel 2, pendidikan petani perempuan pemilik sawah didominasi oleh petani yang tidak sekolah dan SD, masing-masing sebanyak 10 orang. Pemilik sawah yang menempuh Pendidikan sampai perguruan tinggi hanya 2 orang. Sementara itu, mayoritas petani perempuan buruh menempuh jenjang pendidikan hingga SD (16 orang) dan tidak satupun petani dalam sampel yang menempuh pendidikannya hingga perguruan tinggi.

\section{Akses Media}

a. Kepemilikan Telepon Genggam (HP) dan Akses ke Media Sosial

Salah satu hal yang dapat meningkatkan peran perempuan adalah akses pada informasi. Saat ini, informasi lebih cepat berkembang dan tersebar melalui telepon genggam (HP) yang selanjutnya dapat dimanfaatkan untuk mengakses sosial media. Kepemilikan HP dan pemanfaatannya terhadap sosial media petani perempuan disajikan dalam Gambar 1 dan 2 sebagai berikut: 


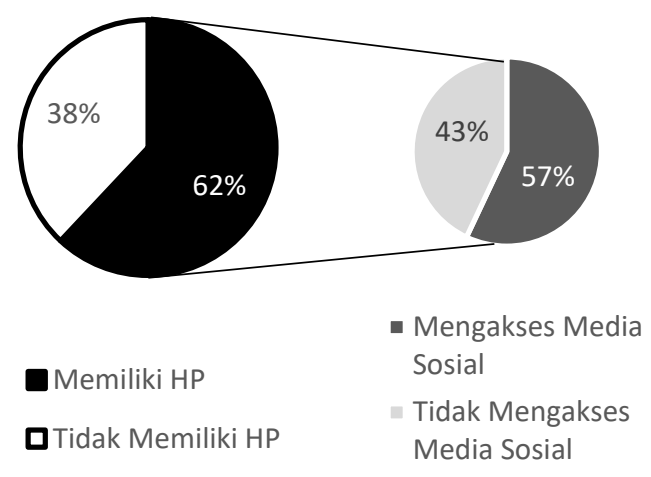

Gambar 1. Kepemilikan HP dan Pemanfaatan Sosial Media Petani Perempuan Pemilik Sawah

Berdasarkan Gambar 1, dapat dilihat bahwa dari 37 responden petani perempuan pemilik sawah, sebesar $62 \%$ (23 petani) tidak memiliki HP. Atau dengan kata lain hanya $38 \%$ (14 petani) yang memiliki HP. Dari 14 petani perempuan pemilik sawah yang memiliki HP, 57\% (8 petani) mengakses media sosial (WA dan/atau FB). sementara itu sisanya $43 \%$ ( 6 petani) tidak mengakses media sosial (WA dan/atau FB).

Jumlah petani yang memiliki HP dan sosial media berbeda antara petani perempuan pemilik sawah dengan petani buruh. Dari 37 responden petani perempuan buruh, sebesar $76 \%$ (28 petani) tidak memiliki HP. Atau dengan kata lain hanya $24 \%$ (9 petani) yang memiliki HP. Dari 9 petani perempuan buruh yang memiliki HP, hanya 33\% (3 petani) saja yang mengakses media sosial (WA dan/atau FB). sementara itu sisanya $67 \%$ (6 petani) tidak mengakses media sosial (WA dan/atau FB). Jumlah tersebut ditunjukkan dalam Gambar 2 berikut ini:

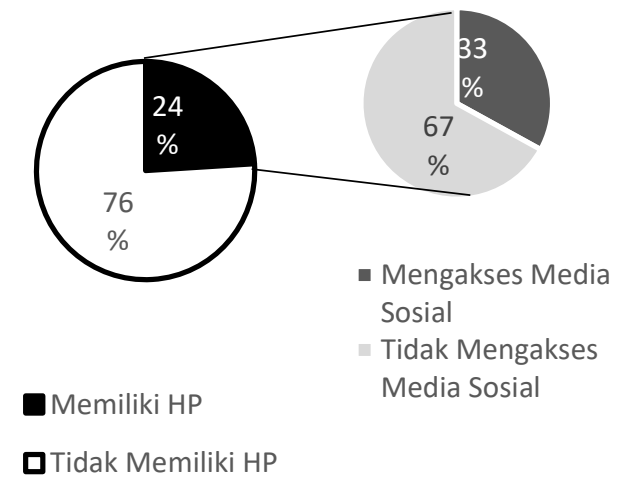

Gambar 2 Kepemilikan HP dan Pemanfaatan Sosial Media Petani Petani Perempuan Buruh

Perbandingan Akses Sosial media antara Petani Perempuan Pemilik Sawah dan Buruh dirangkum dalam Gambar 3 sebagai berikut: 


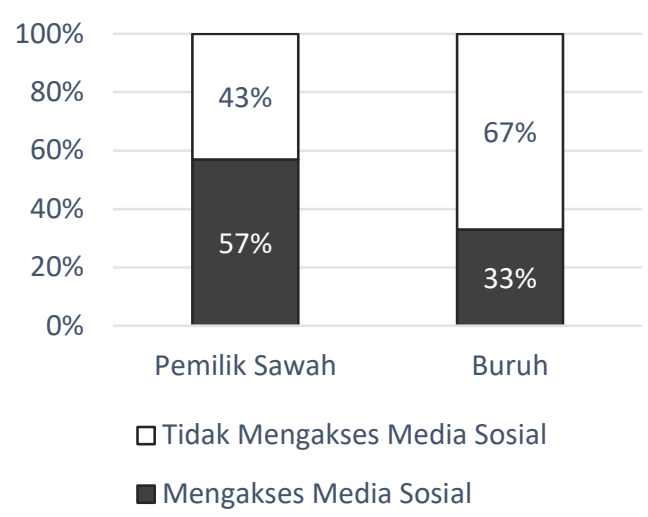

Gambar 3 Perbandingan Akses Sosial media antara Petani Perempuan Pemilik Sawah dan Petani Perempuan Buruh

Sumber: Data primer, diolah (2019)

Gambar 3 menunjukkan perbandingan akses sosial media antara petani perempuan pemilik sawah dan buruh. Dari seluruh petani perempuan pemilik sawah yang memiliki HP, 57\% mengakses media sosial. Sementara itu, dari seluruh petani perempuan buruh hanya 33\% yang memanfaatkannya untuk mengakses sosial media. Artinya, petani perempuan pemilik sawah memiliki kesempatan yang lebih besar untuk meningkatkan pemberdayaan perempuan melalui akses media sosial atau media informasi.

\section{Kegiatan yang Dapat Dihadiri}

Berdasarkan hasil wawancara dengan 74 petani perempuan di Desa Sumberharjo, terdapat perbedaan pendapat mengenai akses petani perempuan pemilik tanah dan buruh terhadap kegiatan yang diselenggarakan di desa. Rincian informasi tersebut disajikan dalam Gambar 4 dan 5.

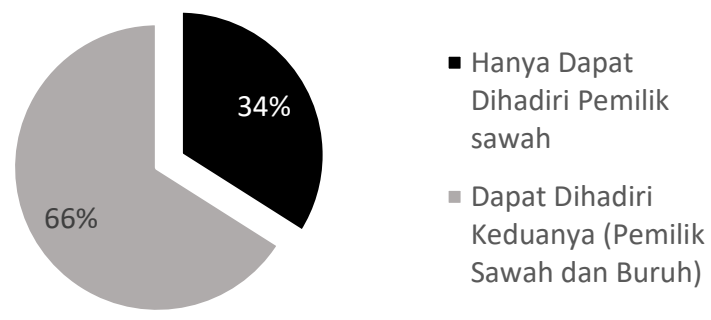

Gambar 4 Perbedaan Kegiatan yang Dapat Dihadiri oleh Pemilik Sawah dan Buruh Sumber: Data primer, diolah (2019)

Gambar 4 menunjukkan bahwa dari 74 petani perempuan, sebanyak 66\% (49 petani) menyatakan bahwa tidak ada perbedaan kegiatan yang dapat dihadiri oleh petani perempuan yang memiliki sawah maupun buruh. Artinya, seluruh kegiatan yang 
diadakan di Desa Sumberharjo dapat dihadiri oleh semua petani perempuan. Namun, sebanyak 34\% (25 petani) menyatakan ada beberapa kegiatan yang hanya bisa dihadiri oleh petani perempuan yang memiliki sawah. Dari 25 petani tersebut, 20 orang diantaranya menyatakan bahwa kegiatan tersebut adalah kegiatan Kelompok Wanita Tani (KWT) dusun yang meliputi kegiatan simpan pinjam, pengembangan program pertanian bersama PPL, serta laporan bulanan kegiatan KWT. Sementara itu, 5 petani lainnya menyebutkan kegiatan yang hanya bisa dihadiri oleh pemilik sawah adalah penyuluhan pertanian yang meliputi penyuluhan terhadap pemberantasan hama dan penanaman tembakau.

Selain akses kegiatan desa, akses terhadap informasi seputar pertanian juga menjadi perdebatan antar sampel penelitian. Hal tersebut dijetunjukkan pada Gambar 5 sebagai berikut:
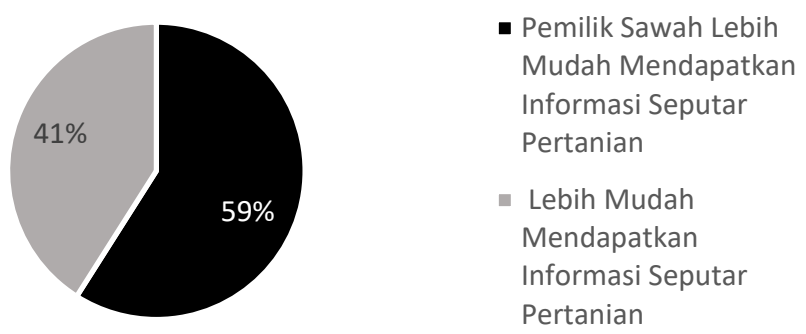

Gambar 5 Perbedaan Kegiatan yang Dapat Dihadiri oleh Pemilik Sawah dan Buruh Sumber: Data primer, diolah (2019)

Berdasarkan Gambar 5, dapat diketahui bahwa dari 74 sampel petani perempuan, sebanyak 59\% (44 petani) menyatakan setuju jika petani perempuan yang memiliki sawah lebih mudah mendapatkan informasi seputar pertanian, seperti harga padi dan pupuk. Sedangkan 41\% (30 petani) menyatakan tidak setuju jika petani perempuan yang memiliki sawah lebih mudah mendapatkan informasi seputar pertanian. Dari pendapat tersebut, dapat disimpulkan bahwa petani perempuan akan lebih mudah memperoleh informasi seputar pertanian ketika memiliki sawah sendiri. Berdasarkan hasil wawancara mendalam, hal tersebut dikarenakan pembelian benih padi, pupuk, dll dilakukan oleh pemilik sawah. Sementara itu, penggarap atau buruh hanya tinggal mengerjakan kegiatan bertani, seperti menanam padi, memupuk, memberantas hama sesuai dengan keinginan pemilik sawah. Selain itu, pemilik sawah juga bisa mendapatkan informasi terkait pertanian melalui sesama pemilik lahan pertanian maupun melalui Kelompok Wanita Tani (KWT) dusun. Petani perempuan yang tergabung dalam KWT dusun memiliki keuntungan tersendiri antara lain mendapatkan informasi terkait dengan harga padi dan pupuk. 


\section{Strategi Peningkatan Pemberdayaan Petani Perempuan}

Hasil analisis menunjukkan bahwa rata-rata pendapatan petani perempuan buruh lebih besar dibandingkan petani perempuan yang memiliki sawah. Hal tersebut menunjukkan salah satu keuntung atau kelebihan sebagai buruh. Dalam segi pendidikan tidak jauh berbeda antara petani perempuan pemilik sawah dan buruh yaitu mayoritas berpendidikan SD. Sementara itu, berkaitan dengan pemberdayaan perempuan baik melalui akses media maupun kegiatan yang dapat dihadiri, masingmasing memiliki kelebihan dan kekurangan. Petani perempuan pemilik sawah memiliki kesempatan yang lebih besar untuk meningkatkan pemberdayaan perempuan melalui akses media sosial atau media informasi.

Salah satu talenta yang dimiliki perempuan adalah kemampuan membangun jaringan dan komunikasi. Hal tersebut disampaiakn oleh Najih (2017) dalam penelitiannya tentang Gender dan Kemajuan Teknologi. Dalam tulisannya, Najih juga menyampaikan bahwa dengan kepribadian yang mudah membentuk komunitas, perempuan memanfaatkan era teknologi informasi melalui media internet, misalnya perdagangan online. Melalui media tersebut, bakat marketing yang dimiliki dapat dimanfaatkan untuk memaksimalkan pemasaran produk yang dimiliki.

Pengaruh media sosial terhadap pemberdayaan perempuan juga didukung oleh penelitian Purwidiantoro, dkk (2016). Penelitian tentang pengaruh penggunaan media sosial terhadap pengembangan Usaha Kecil Menengah (UKM) menyimpulkan bahwa media sosial bermanfaat bagi UKM untuk komunikasi personal dengan konsumen, Pemasaarn dan iklan, mendata kebutuhan konsumen, memberikan respon pada konsumen, membantu pengambilan keputusan dan sebagai forum diskusi dengan konsumen. Berdasarkan penelitian penggunaan media sosial dapat meningkatkan penjualan hingga lebih dari 100\% apabila perusahaann melakukan update informasi secara konsisten melalui media sosial setiap hari.

Selain akses terhadap media, pemberdayaan perempuan dapat ditingkatkan melalui keaktifan petani perempuan untuk mengemukakan pendapat di depan umum, salah satunya melalui kehadiran dalam setiap kegiatan yang diselenggarakan di desa. Dalam paper Holland \& Rammohan (2019) ditunjukkan indikator pemberdayaan perempuan menurut Women's Empowerment in Agriculture Index (WEAI) yang merupakan data indeks yang ditugaskan oleh agensi Amerika Serikat dan divalidasi oleh Institut Penelitian Kebijakan Pangan Internasional, dan pembangunan manusia dan kemiskinan Oxford. Salah satu indikator indeks tersebut adalah group membership speaking in public. Dalam indikator tersebut, perempuan dikatakan berdaya jika: 1) perempuan tersebut merupakan anggota minimal dalam satu grup atau kelompok sosial; dan 2) merasa nyaman berbicara di depan publik mengenai hal yang berkaitan dengan dirinya, anggota keluarganya maupun kelompoknya. Berdasarkan indikator tersebut, petani perempuan yang ada di Desa Sumberharjo belum optimal dalam mendapatkan kesempatan untuk mengaktualisasikan dirinya dalam sebuah grup atau kelompok di desanya. Hal 
tersebut karena masih terdapat petani perempuan yang menyatakan bahwa ada beberapa kegiatan yang hanya bisa dihadiri oleh petani perempuan yang memiliki sawah. Selain itu, petani perempuan lebih mudah mendapatkan informasi tentang pertanian jika memiliki lahan sendiri. Mereka dapat memperoleh informasi dari kelompok tani perempuan di desanya. Dari beberapa hasil analisis tersebut, terdapat peluang untuk meningkatkan pemberdayaan petani perempuan di Desa Sumberharjo. Untuk mengetahui strategi yang tepat dalam meningkatkan pemberdayaan petani perempuan, dilakukan analisis SWOT.

Tabel 3 Matriks SWOT Petani Perempuan Pemilik Sawah dan Buruh

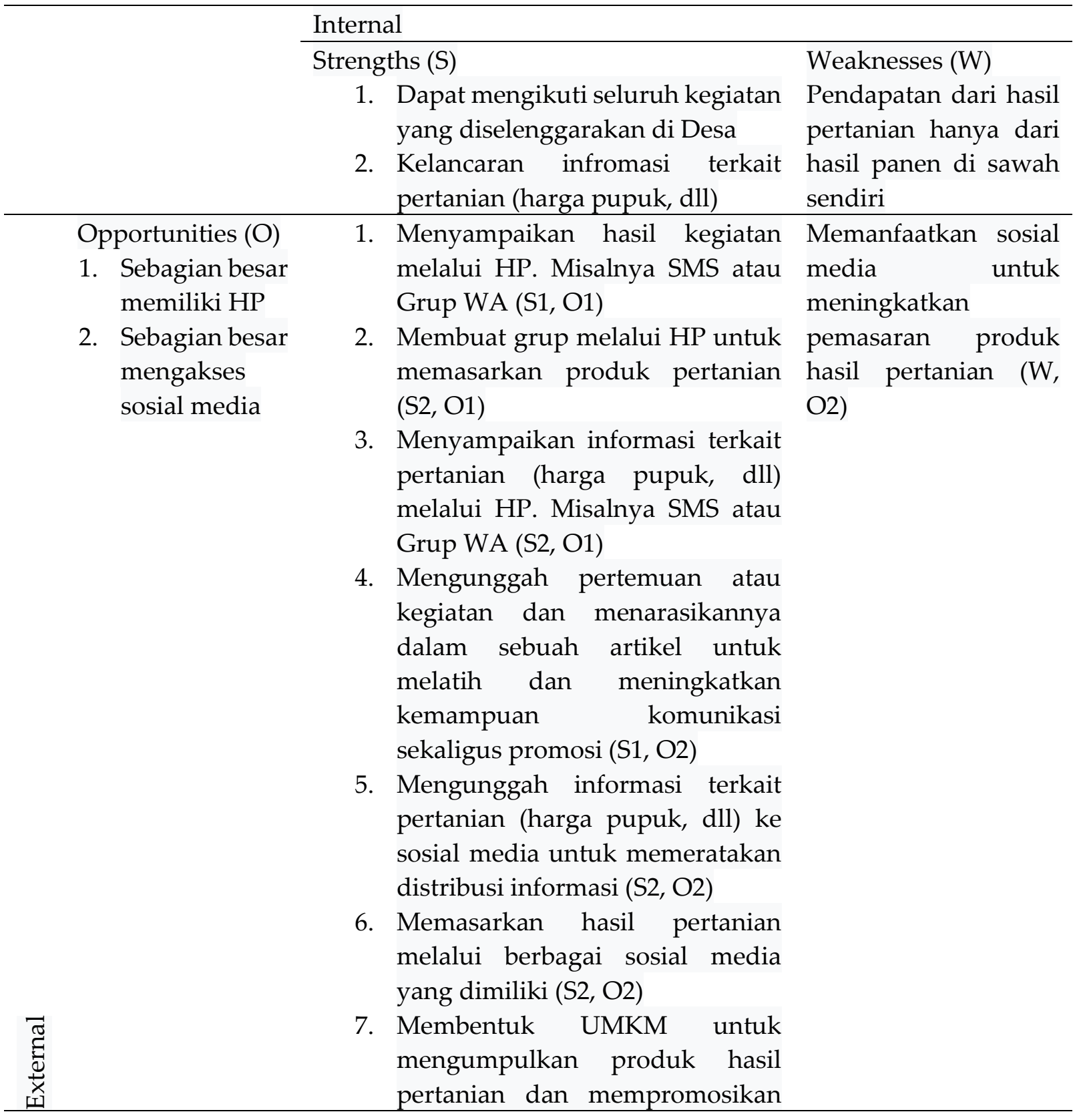


serta memasarkannya melalui berbagai sosial media (S1, S2, O2)

Threats (T)

1. Gagal panen

2. Harga hasil panen murah
1. Menyusun alternatif pencegahan gagal panen antar petani melalui pertemuan desa (S1, T1)

2. Menyusun alternatif diversifikasi dan modifikasi pemasaran hasil pertanian untuk meningkatkan nilai tambah dan nilai jual produk (S1, S2, W, T2)

Sumber: data diolah

Tabel 4 Matriks SWOT Petani Perempuan Buruh

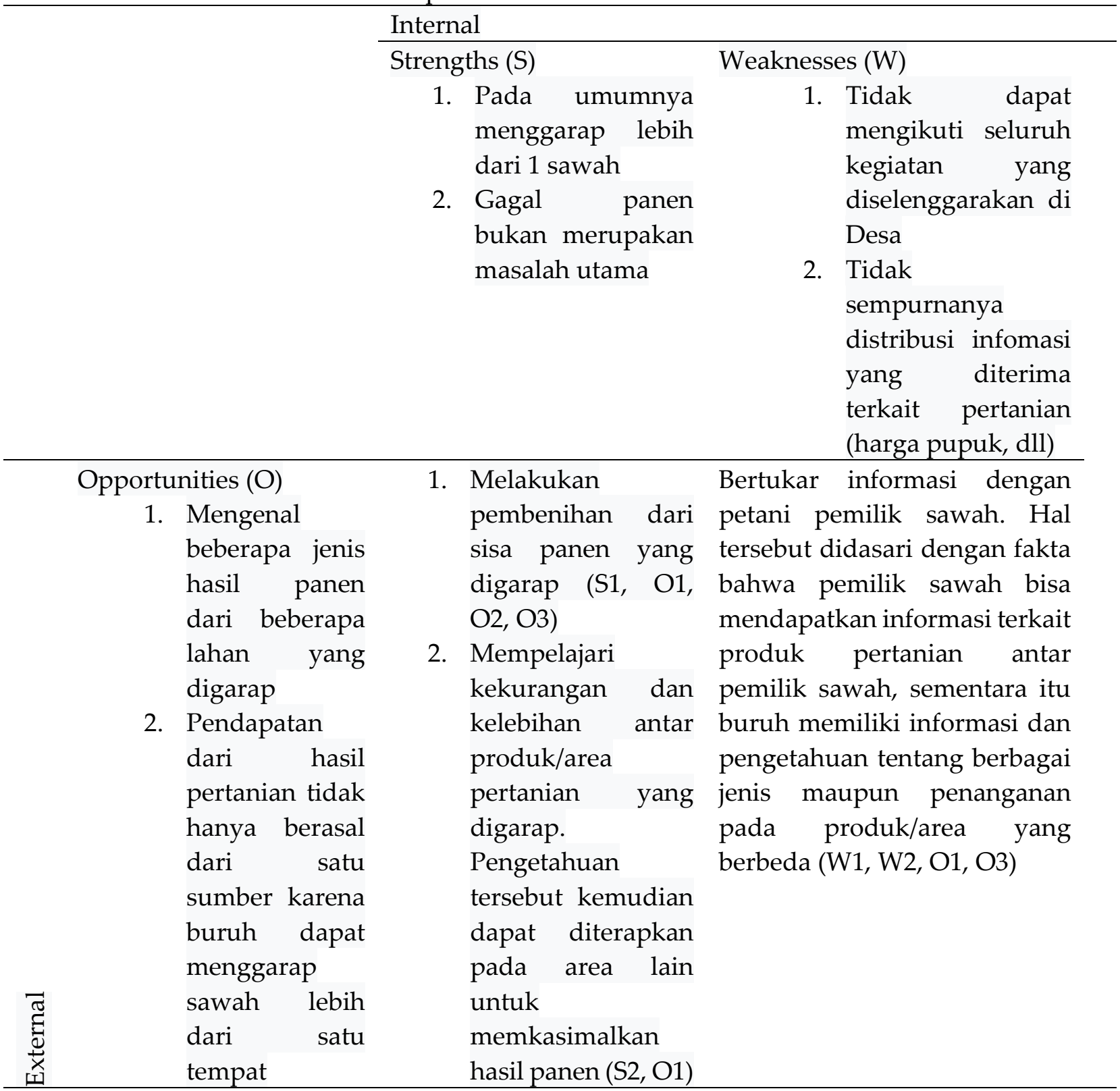


3. Selain upah

buruh, buruh

juga

mendapatkan

bagian hasil

panen

(meskipun

dalam jumlah

sedikit)

Threats (T)

1. Hanya sebagian kecil buruh yang memiliki $\mathrm{HP}$

2. Hanya sebagian kecil buruh yang mengakses sosial media

3. Kompetisi skill antar buruh. Pemilik sawah memiliki hak penuh untuk memilih siapa buruh yang dipercaya untuk menggarap sawahnya
1. Memanfaatkan

pengalaman

bertani dengan

meningkatkan

kemampuan

dalam mengelola

sawah, antara lain

dengan mengenali

kelebihan dan

kekurangan

masing-masing

jenis dan kondisi tanaman (S1, T3)

2. Bagi buruh yang memiliki HP dan sosial media mendistribusikan informasi terkait pertanian yang diperoleh dari HP dan sosial media kepada buruh yang tidak memiliki HP dan sosial media (S1, T1, T2, W1, W2)

3. Membentuk komunitas atau perkumpulan buruh tani untuk meningkatkan informasi dan bertukar pengalaman terkait pertanian. Selain itu, komunitas dapat meningkatkan kemampuan komunikasi dan negosiasi untuk mendukung pemberdayaan perempuan $(\mathrm{S} 1, \mathrm{~S} 2, \mathrm{~W} 1, \mathrm{~W} 2, \mathrm{O} 1, \mathrm{O} 2, \mathrm{O} 3, \mathrm{~T} 1, \mathrm{~T} 2, \mathrm{~T} 3)$

4. Bekerja sama mempersiapkan diversifikasi produk dari hasil pembenihan yang siap jual untuk dipasarkan melalui sosial media dengan peran buruh yang memiliki HP dan sosial media (S1, S2, W1, W2, O1, O2, O3, T1, T2, T3)

5. Membentuk UMKM untuk mengumpulkan produk hasil pertanian dan mempromosikan serta memasarkannya melalui berbagai sosial media dengan peran buruh yang memiliki HP dan sosial media (S1, S2, W1, W2, O1, O2, O3, $\mathrm{T} 1, \mathrm{~T} 2, \mathrm{~T} 3)$

Sumber: data diolah

Beberapa strategi yang dihasilkan Matriks SWOT pada Tabel 3 dan 4 merupakan gabungan seluruh kekuatan (strengths), kelemahan (weaknesses), peluang (opportunities), dan ancaman (threats) yang dimiliki dan dihadapi oleh Petani Perempuan Pemilik Sawah di Desa Sumberharjo. Pada Tabel 3, secara umum strategi untuk petani perempuan pemilik sawah adalah memanfaatkan HP maupun media sosial untuk meningkatkan pemberdayaan perempuan petani, terutama dalam hal komunikasi dan pemasaran. 
Berdasarkan beberapa strategi yang terbentuk dalam Tabel 4, peningkatan skill pertanian dan keaktivan dalam komunitas atau kelompok buruh merupakan peran penting dalam membantu meningkatkan pemberdayaan petani perempuan buruh di Desa Sumberharjo, Kecamatan Prambanan.

\section{KESIMPULAN}

\section{Kesimpulan}

Rata-rata pendapatan hasil bertani petani perempuan buruh lebih besar dibandingkan petani perempuan pemilik sawah. Berdasarkan hasil wawancara, hal tersebut karena petani buruh tidak hanya menggarap satu sawah saja, sedangkan pemilik sawah hanya menerima hasil hanya dari sawahnya.

Karakteristik pendidikan petani perempuan di Desa Sumberharjo yaitu mayoritas petani perempuan buruh memiliki pendidikan SD, sementara pendidikan petani perempuan yang memiliki sawah didominasi oleh petani yang berpendidikan SD dan tidak mengenyam pendidikan, masing-masing sebanyak 10 orang. Pemilik sawah yang menempuh Pendidikan sampai perguruan tinggi hanya 2 orang. Sementara itu, mayoritas petani perempuan buruh menempuh jenjang Pendidikan hingga SD (16 orang) dan tidak satupun petani dalam sampel yang menempuh pendidikannya hingga perguruan tinggi.

Terkait akses media sosial, dari 37 responden petani perempuan pemilik sawah, hanya 14 petani yang memiliki HP dan 8 orang diantaranya mengakses media sosial (WA dan/atau FB). sementara itu, dari 37 responden petani perempuan buruh, hanya 9 petani yang memiliki HP. Dari 9 petani tersebut hanya 3 petani saja yang mengakses media sosial (WA dan/atau FB). Dari hasil tersebut, menunjukkan bahwa petani perempuan pemilik sawah memiliki kesempatan yang lebih besar untuk meningkatkan pemberdayaan perempuan melalui akses media informasi.

Berkaitan dengan kegiatan di Desa Sumberharjo, dari 74 sampel petani perempuan, sebanyak 49 orang menyatakan bahwa tidak ada perbedaan kegiatan yang dapat dihadiri oleh petani perempuan yang memiliki sawah maupun buruh. Artinya, seluruh kegiatan yang diadakan di Desa Sumberharjo dapat dihadiri oleh semua petani perempuan. Namun, sebanyak 25 orang menyatakan ada beberapa kegiatan yang hanya bisa dihadiri oleh petani perempuan yang memiliki sawah. Dari 25 orang tersebut, 20 orang diantaranya menyatakan bahwa kegiatan tersebut adalah kegiatan KWT (Kelompok Wanita Tani) dusun yang meliputi kegiatan simpan pinjam, pengembangan program pertanian bersama PPL, serta laporan bulanan kegiatan KWT. Sementara itu, 5 lainnya menyatakan bahwa kegiatan yang hanya bisa dihadiri oleh pemilik sawah adalah penyuluhan pertanian yang meliputi penyuluhan terhadap pemberantasan hama dan penanaman tembakau. Berdasarkan hal tersebut, dapat disimpulkan bahwa petani perempuan akan lebih mudah memperoleh informasi seputar pertanian ketika memiliki sawah sendiri. Pemilik sawah juga dapat 
mendapatkan informasi terkait pertanian melalui KWT dusun dan antar sesama pemilik lahan pertanian.

Upaya lain untuk meningkatkan pemberdayaan perempuan adalah strategi yang disusun dengan mempertimbangkan kekuatan (strengths), kelemahan (weaknesses), peluang (opportunities), dan ancaman (threats). Secara umum strategi untuk petani perempuan pemilik sawah adalah memanfaatkan HP maupun media sosial untuk meningkatkan pemberdayaan perempuan petani, terutama dalam hal komunikasi dan pemasaran. Sementara itu, bagi petani perempuan buruh, peningkatan skill pertanian dan keaktivan dalam komunitas atau kelompok buruh merupakan peran penting dalam membantu meningkatkan pemberdayaan petani perempuan buruh.

\section{Rekomendasi Kebijakan}

Berdasarkan hasil penelitian, berikut saran yang dapat digunakan sebagai pertimbangan untuk meningkatkan pemberdayaan petani perempuan di Desa Sumberharjo:

1. Pemerintah Desa Sumberharjo mendukung dan memotivasi pembentukan komunitas petani buruh. Misalnya, aktif menyampaikan informasi kelebihan dan keuntungan suatu komunitas atau kelompok.

2. Rutin mendata hasil pertanian untuk diangkat menjadi produk UMKM. Selanjutnya pemerintah desa memfasilitasi informasi pemasaran yang potensial. Misalnya, mengikutsertakan anggota UMKM untuk mengikuti pameran UMKM.

3. Pemerintah Desa Sumberharjo menyediakan media untuk menyebarkan informasi terkait pertanian, seperti harga pupuk dan harga hasil panen kepada seluruh petani. Misalnya dengan membuat jaringan broadcast baik secara daring maupun luring disesuaikan dengan kondisi masyarakat. Perangkat desa yang berwenang menyebarkan informasi kepada pejabat dibawahnya dan memastikan bahwa informasi tersebut sampai kepada masyarakat.

4. Pemerintah Desa Sumberharjo melibatkan seluruh petani perempuan secara bergantian dalam setiap kegiatan tanpa memilih status kepemilikan lahan. Karena baik pemilik lahan maupun buruh sama-sama membutuhkan informasi terkait pertanian.

\section{DAFTAR PUSTAKA}

Agarwal, B. (1997). Bargaining and gender relations: Within and beyond the household. Feminist Economics, 3(1), 1-51.

Allendorf, K. (2007). Do women's land rights promote empowerment and child health in Nepal?. World Development, 35(11), 1975-1988.

Anderson, S., \& Eswaran, M. (2009). What determines female autonomy? Evidence from Bangladesh. Journal of Development Economics, 90(2), 179-191. 
Anukriti, S. (2014). The fertility-sex ratio trade-off: Unintended conse-quences of financial incentives (No. 8044). IZA Discussion Paper. (Retrieved from $<$ http://www.econstor.eu/handle/10419/96793>).

Bhandari, R. (2001). Land and labor markets among paddy producers in the Nepalese Tarai. Doctoral Dissertations Available from Proquest, 1-334.

Bogdan, R. and Taylor, S.J. (1975). Introduction to Qualitative Research Methode. New York: John Willey and Sons.

D. W. Hosmer Jr and S. Lemeshow. (2004). Applied logistic regression. John Wiley \& Sons.

Doss, C. (2006). the effects of intrahousehold property ownership on expenditure patterns in Ghana. Journal of African Economies, 15(1), 149-180. http://dx.doi.org/10.1093/jae/eji025

Duflo, E. (2003). Grandmothers and granddaughters: Old-age pensions and intrahousehold allocation in South Africa. The World Bank Economic Review, 17(1), $1-25$.

FAO. (2010). Female land ownership. (Retrieved from <http://www.fao.org/ economic/es-policybriefs/multimedia0/female-land-ownership/en/>, June 30, 2014).

Ghozali, Imam. (2011). Aplikasi Analisis Multivariate Dengan Program SPSS. Semarang: Badan Penerbit Universitas Diponegoro.

Holland, Cara \& Rammohan, Anu. (2019). Rural women's empowerment and children's food and nutrition security in Bangladesh. World Development, 124, 104648.

Mason, K. O. (1996). Wives economic decision-making power in the family in five Asian countries. Honolulu, Hawaii, East-West Center, Population Series No. 86. (Retrieved from <http://www.popline.org/ node/313642>).

Menon, N., van der Meulen Rodgers, Y., \& Nguyen, H. (2014). Women's land rights and children's human capital in Vietnam. World Development, 54, 18-31.

Mishra, Khushbu \& Sam, A. G. (2016). Does Women's Land Ownership Promote Their Empowerment? Empirical Evidence from Nepal. World Development Vol. 78, pp. 360-371.

Mustaffa, C. S. \& Asyiek, F. 2015. Conceptualizing Framework for Women Empowerment in Indonesia: Integrating the Role of Media, Interpersonal Communication, Cosmopolite, Extension Agent and Culture as Predictors Variables. Asian Social Science; Vol. 11, No. 16.

Najih, Muhammad Aqibun. 2017. Gender dan Kemajuan Teknologi: Pemberdayaan Perempuan Pendidikan dan Keluarga. HARKAT: Media Komunikasi Islam tentang Gender dan Anak, 12 (2).

Pandey, S. (2010). Rising property ownership among women in Kath-mandu, Nepal: An exploration of causes and consequences. International Journal of Sosial Welfare, 19(3), 281-292. 
Prasekti, Y. H. (2017). Peran Wanita Tani dalam Menunjang Perekonomian Rumah Tangga Keluarga Petani. Jurnal Agribisnis, Vol. 13 No. 15.

Purwidiantoro, Moch Hari., W. Dany Fajar Kristanto S., dan Hadi, Widiyanto. 2016.

Pengaruh Penggunaan Media Sosial terhadap Pengembangan Usaha Kecil Menengah (UKM). Jurnal EKA CIDA Vol. 1 No. 1.

Rangkuti, Freddy. (2006). Analisis SWOT Teknik Membedah Kasus Bisnis: Reorientasi

Konsep Perencanaan Strategis untuk Menghadapi Abad 21. Jakarta: PT Gramedia Pustaka Utama.

Rogers, EM. (1983). Diffusion of innovations (3rd edition). The Free Press. A Division of Macmillan Publishing Co., Inc. New York. Collier Macmillan Publishers, London.

Saragih, B. (2000). Sektor agribisnis jalan keluar krisis dan menuju kejayaan ekonomi nasional. Artikel Sinar tani, 6-12 Spetember 2000, No. 2858 Tahun XXXI.

Sharma, S. (1999). Land tenure and poverty in Nepal. In WDR-2000 consultation meeting organized by the World Bank. (Retrieved from http://siteresources.worldbank.org/INTPOVERTY/Resources/WDR/dhaka/shar ma.pdf).

SOFA Team \& Doss, C. (2011). The role of women in agriculture. Economic Development Analysis Division (ESA) Working Paper, 11-02. Food and Agricultural Organization. Agricultural Development Economics Division (Retrieved from <http://www.fao.org/docrep/013/ am307e/am307e00.pdf>).

Sraboni, Esha \& Quisumbing, Agnes. (2018). Women's empowerment in agriculture and dietary quality across the life course: Evidence from Bangladesh. Food Policy, 81, 21-36.

Sugiyono. (2017). Metode Penelitian Kuantitatif, Kualitatif, dan RED. Bandung: Alfabeta, CV.

Suparta, N. (2001). Perilaku agribisnis dan kebutuhan penyuluhan peternak ayam ras pedaging (Disertasi). Bogor: Program Pascasarjana IPB.

Thomas, D. (1990). Intra-household resource allocation: An inferential approach. The Journal of Human Resources, 25(4), 635-664.

Wiig, H. (2013). Joint titling in rural Peru: Impact on women's participation in household decision-making. World Development, 52, 104-119.

https://kependudukan.jogjaprov.go.id/olah.php?module=statistik\&periode=11\&jenis data $=$ kepala\&berdasarkan=pekerjaan\&prop $=34 \& k a b=04 \& k e c=09, \quad$ (online), diakses 17 Mei 2019.

https://slemankab.bps.go.id/subject/53/tanaman-pangan.html\#subjekViewTab3, (online), diakses 4 April 2019.

https://sustainabledevelopment.un.org/?menu=1300, (online), diakses 4 April 2019. https://www.care.org/our-work/womens-empowerment/genderintegration/womens-empowerment-framework, (online), diakses 4 April 2019. 
https://www.kemenpppa.go.id/index.php/page/read/31/1439/mencapai-kesetaraangender-dan-memberdayakan-kaum-perempuan, (online), diakses 4 April 2019. https://www.un.org/en/ecosoc/newfunct/pdf/womens_empowerment_principles_pp t_for_29_mar_briefing-without_notes.pdf, (online), diakses 4 April 2019. https://www.undp.org/content/undp/en/home/sustainable-development-goals.html, (online), diakses 4 April 2019. 